\title{
Improved micropropagation of Bacopa monnieri (L.) Wettst. (Plantaginaceae) and antimicrobial activity of in vitro and ex vitro raised plants against multidrug-resistant clinical isolates of urinary tract infecting (UTI) and respiratory tract infecting (RTI) bacteria
}

Sk Moquammel Haque ${ }^{1}$, Avijit Chakraborty', Diganta Dey², Swapna Mukherjee ${ }^{3}$, Sanghamitra Nayak ${ }^{4}$ and Biswajit Ghosh ${ }^{1 *}$

\begin{abstract}
Background: Nowadays the multidrug-resistant (MDR) bacterial pathogens are a major concern of the medical science. Medicinal plants may be considered as new sources for producing antibacterial agents. The present study aimed to standardize an improved method for micropropagation and in vitro biomass production of Bacopa monnieri. Second aim is to evaluate the antimicrobial potency of in vitro cultured and ex vitro field grown micropropagated plants against different MDR clinical isolates of human urinary tract infecting (UTI) and respiratory tract infecting (RTI) pathogens.

Methods: Micropropagation of B. monnieri were performed following standard tissue culture method. The role of 6-benzylaminopurine (BAP), kinetin and spermidine on multiple shoot induction were evaluated. Antimicrobial activity of ethanol, methanol and acetone extract of in vitro and ex vitro plants of $B$. monnieri were screened by agar cup method against five MDR-UTI bacteria, four MDR-RTI bacteria and three microbial type culture collection (MTCC) bacteria and two fungi. Minimum inhibitory concentration (MIC), minimum bactericidal concentration (MBC) and minimum fungicidal concentration (MFC) were also determined.

Results: Synergistic effect of BAP and spermidine had improved shoot induction with a maximum of 123.8 shoot-buds per explant. Optimum micropropagation with 34.9 elongated shoots per explant was recorded in Murashige and Skoog medium containing $1.5 \mathrm{mg} / \mathrm{L}$ BAP and $2.0 \mathrm{mM}$ spermidine. Methanolic extract of ex vitro plants showed maximum activity against MDR-UTI strain of Escherichia coli (sample-9) [ZI $18 \pm 0.68 \mathrm{~mm}$, MIC $2.5 \mu \mathrm{g} / \mathrm{mL}, \mathrm{MBC} 5.0 \mathrm{\mu g} / \mathrm{mL}$ ]. Acetone extract of ex vitro plant exhibited maximum inhibition against MDR-RTI strain of Klebsiella pneumoniae (sample-38) [ZI $14 \pm 0.22 \mathrm{~mm}$, MIC $5.0 \mu \mathrm{g} / \mathrm{mL}, \mathrm{MBC} 7.5 \mu \mathrm{g} / \mathrm{mL}]$. The extracts of $B$. monnieri were bactericidal rather than bacteriostatic against all UTI and RTI bacteria tested.

(Continued on next page)
\end{abstract}

\footnotetext{
* Correspondence: ghosh_b2000@yahoo.co.in

${ }^{1}$ Plant Biotechnology Laboratory, Post Graduate Department of Botany,

Ramakrishna Mission Vivekananda Centenary College, Rahara, Kolkata 700118,

India

Full list of author information is available at the end of the article
} 
(Continued from previous page)

Conclusions: The present manuscript demonstrated an efficient in vitro method for large scale biomass production of B. monnieri. Furthermore, the methanolic extract of B. monnieri have potential antimicrobial activity against clinical isolates of MDR-UTI and MDR-RTI bacterial strains. Hence this plant may further use to treat these infectious diseases. The comparative results show ex vitro grown plants have slightly better antimicrobial activities as compared to the in vitro plants.

Keywords: Bacopa monnieri, Clinical isolates, Micropropagation, Multidrug-resistant, RTI bacteria, Spermidine, UTI bacteria,

\section{Background}

In more than $80 \%$ of developed countries, plants have been traditionally used as remedy because they are the actual good source of different pharmacologically active compounds [1]. Bacopa monnieri (L.) Wettst. (family Plantaginaceae) is an important medicinal plant grown throughout the Indian subcontinent and traditionally been used in Ayurvedic system of medicine [2,3]. This species is one of the best versatile 'tonic herbs' stimulates brain, heart, liver, and kidney health. It also used as a revitaliser of sensory organs, water retention and blood cleaning, relaxant, neuroprotective as well as in the treatment of allergic disorders of skin, snake bite, enlargement of the spleen, rheumatism, leprosy, epilepsy, asthma, hoarseness and anxiety. Bacopa monnieri extract has proven sedative, antiinflammatory and antipyretic, anti-cancer, anti-oxidant, immuno-modulatory, antiulcerogenic, antistress, antileishmanial, antipyretic, analgesic and anti-aging properties [4-9]. Kishore [6] had designated B. monnieri as a "complete herbal medicine" due to multipurpose usage of this wonder medicinal plant. The antimicrobial property of B. monnieri was previously screened by few scientists, but majority of this reports are against standard bacterial strains [10-12]. Although one report are available where clinical isolates of human pathogenic strains are tested, but these are not multidrug-resistant (MDR) strains [13]. Antibacterial resistance has become one of the grave public health concerns, globally, over the last two decades [14, 15]. In modern years, there has been a rising interest in investigating and evolving new antimicrobial agents from various sources to combat microbial resistance [16]. The MDR microbial pathogens imply a most important threat to human health. The worldwide surge in MDR bacteria and the proximity of urinary tract infectious and respiratory tract infectious disease demand alternative curative approaches to supplement the existing medications.

Bacopa monnieri was positioned second in a priority list of the most significant medicinal plants, assessed on the basis of their medical reputation, commercial value, and potential for advance research and development by the

Table 1 Antimicrobial activities of nine clinical isolates of the human UTI and RTI bacteria against 15 well known drugs

\begin{tabular}{|c|c|c|c|c|c|c|c|c|c|}
\hline \multirow[t]{2}{*}{ Antibiotics } & \multicolumn{5}{|l|}{ UTI Pathogens } & \multicolumn{4}{|c|}{ RTI Pathogens } \\
\hline & $\begin{array}{l}\text { Sample } 5 \\
\text { (Escherichia coli) }\end{array}$ & $\begin{array}{l}\text { Sample } 9 \\
\text { (Escherichia coli) }\end{array}$ & $\begin{array}{l}\text { Sample } 11 \\
\text { (Escherichia coli) }\end{array}$ & $\begin{array}{l}\text { Sample } 19 \\
\text { (Klebsiella } \\
\text { pneumoniae) }\end{array}$ & $\begin{array}{l}\text { Sample } 26 \\
\text { (Klebsiella } \\
\text { pneumoniae) }\end{array}$ & $\begin{array}{l}\text { Sample } 31 \\
\text { (Klebsiella } \\
\text { pneumoniae) }\end{array}$ & $\begin{array}{l}\text { Sample } 35 \\
\text { (Klebsiella } \\
\text { pneumoniae) }\end{array}$ & $\begin{array}{l}\text { Sample } 36 \\
\text { (Klebsiella } \\
\text { pneumoniae) }\end{array}$ & $\begin{array}{l}\text { Sample } 38 \\
\text { (Klebsiella } \\
\text { pneumoniae) }\end{array}$ \\
\hline Amoxiline & $\mathrm{R}$ & $S$ & $S$ & $\mathrm{R}$ & $\mathrm{R}$ & $\mathrm{R}$ & $\mathrm{R}$ & $\mathrm{R}$ & $\mathrm{R}$ \\
\hline Amikacin & $\mathrm{S}$ & $\mathrm{S}$ & S & $\mathrm{R}$ & $\mathrm{R}$ & $\mathrm{S}$ & $\mathrm{S}$ & $\mathrm{R}$ & $\mathrm{R}$ \\
\hline Aztreonam & $\mathrm{R}$ & $\mathrm{R}$ & $\mathrm{R}$ & $\mathrm{R}$ & $\mathrm{R}$ & NT & $\mathrm{R}$ & NT & NT \\
\hline Ceftriaxone & $\mathrm{R}$ & $\mathrm{R}$ & S & $\mathrm{R}$ & $\mathrm{R}$ & $\mathrm{R}$ & $\mathrm{R}$ & $\mathrm{R}$ & $\mathrm{S}$ \\
\hline Cefuroxime & $\mathrm{R}$ & $\mathrm{R}$ & $S$ & $\mathrm{R}$ & 1 & $\mathrm{R}$ & $\mathrm{R}$ & $\mathrm{R}$ & $\mathrm{R}$ \\
\hline Ciprofloxacin & $\mathrm{R}$ & NT & I & 1 & I & $\mathrm{R}$ & $\mathrm{R}$ & $\mathrm{R}$ & $\mathrm{R}$ \\
\hline Piperacillin & $S$ & $S$ & $S$ & $\mathrm{R}$ & S & $S$ & $\mathrm{NT}$ & $\mathrm{R}$ & NT \\
\hline Cefoperazone & $\mathrm{R}$ & NT & $S$ & $\mathrm{R}$ & $\mathrm{R}$ & $S$ & $S$ & $\mathrm{R}$ & $\mathrm{R}$ \\
\hline Ceftazidime & $\mathrm{R}$ & $\mathrm{R}$ & S & $\mathrm{R}$ & $\mathrm{R}$ & NT & NT & $\mathrm{R}$ & $\mathrm{R}$ \\
\hline Ofloxacin & $\mathrm{R}$ & $\mathrm{R}$ & $\mathrm{R}$ & I & $S$ & NT & NT & NT & NT \\
\hline Sulbactum & S & $\mathrm{R}$ & S & $\mathrm{R}$ & S & $\mathrm{R}$ & $\mathrm{R}$ & S & NT \\
\hline Nitrofurantoin & S & $\mathrm{R}$ & $\mathrm{S}$ & NT & $S$ & $\mathrm{R}$ & $\mathrm{R}$ & $\mathrm{S}$ & $\mathrm{S}$ \\
\hline Meropenum & S & NT & NT & 1 & $\mathrm{R}$ & $S$ & $\mathrm{R}$ & $\mathrm{R}$ & $\mathrm{R}$ \\
\hline Doxycycline & S & $\mathrm{R}$ & S & S & S & NT & S & S & $\mathrm{R}$ \\
\hline Norfloxacin & $\mathrm{R}$ & $S$ & $S$ & 1 & $S$ & $\mathrm{R}$ & $\mathrm{R}$ & $\mathrm{R}$ & $\mathrm{R}$ \\
\hline
\end{tabular}

$R$ resistant, $S$ sensitive, $I$ intermediate, $N T$ not tested 
National Medicinal Plants Board of India (2004) [17]. Due to illegal over-collection of the pharmaceutical companies, it has now been depleted from its natural habitat and recognized as an endangered plant of India $[3,18]$. In this circumstances, the demand for good quality planting material of this wonder curative herb is increasing dayafter-day, which necessitate the improvement of the existing micropropagation methods for rapid and constant supply of planting materials round the year. On other hand, land is not available for medicinal plant cultivation as compare to crop plants [19], so in vitro biomass production is alternative option to produce huge amounts of pharmaceutically active compounds round the year without any cultivation land. Although micropropagation of $B$. monnieri has been studied by several group of researchers for more than four decades $[2,3]$, yet based on their wonder medicinal properties, the additional research is much needed for further improvement of the micropropagation protocol. The present study was thus aimed to the-(1) development of high frequency micropropagation method, (2) screening of the antimicrobial activities of different solvent-extracts of $B$. monnieri against various pathogenic strains of MDR bacteria and standard laboratory strains (MTCC) of bacteria and fungi.

\section{Methods}

\section{Surface sterilization and initial culture establishment}

Shoot tips (8-10 mm) of Bacopa monnieri (L.) Wettst. (family Plantaginaceae) were collected from the healthy plants grown in an experimental garden of our college and were washed with $2.5 \%(w / v)$ systematic fungicide (Bavistin) for $15 \mathrm{~min}$ followed by $2.5 \%$ liquid detergent
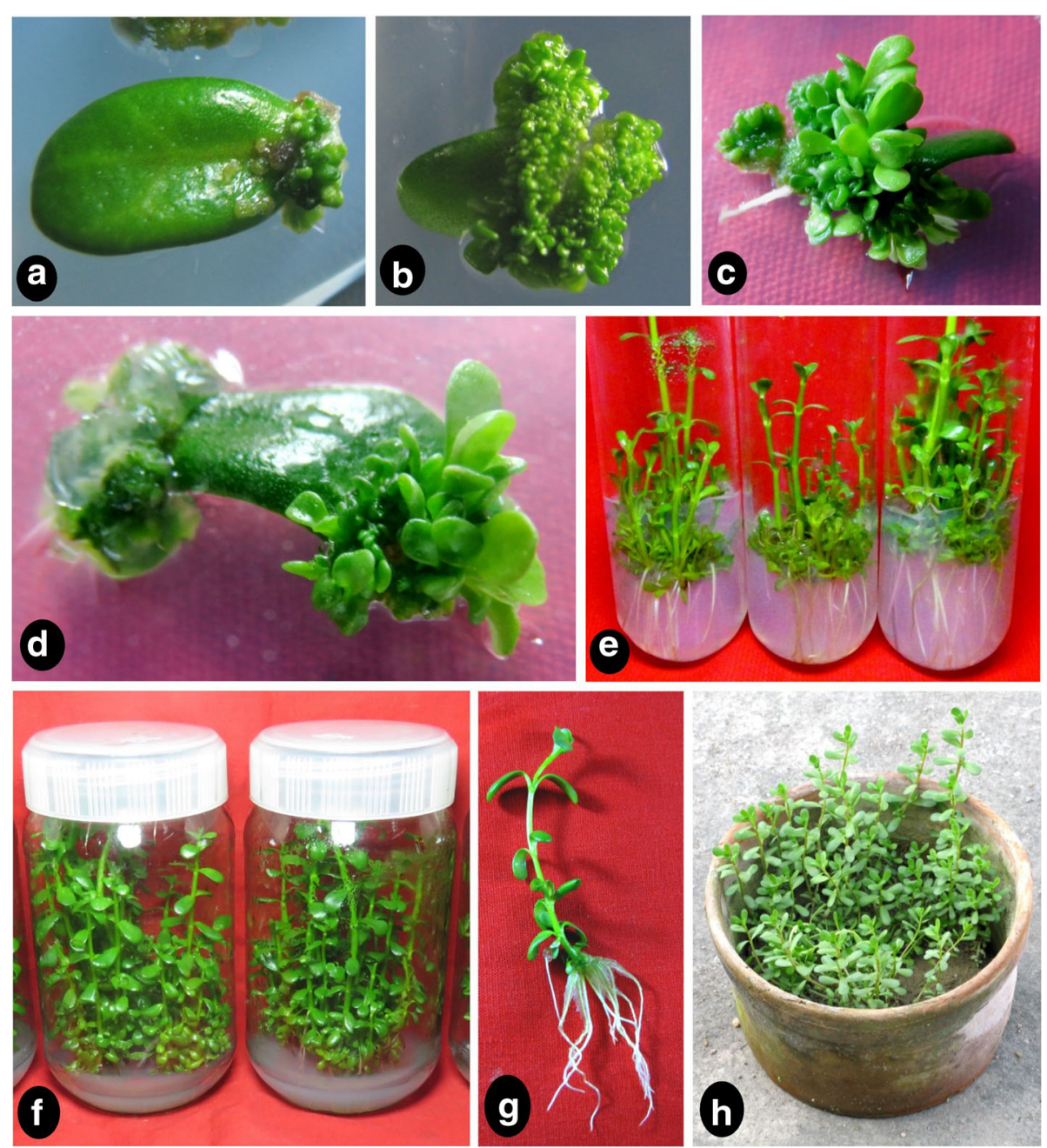

Fig. 1 Different stages of micropropagation of Bacopa monnieri. a Induction of shoot buds from the cut edges of leaf after 8 days of inoculation in medium containing $0.5 \mathrm{mg} / \mathrm{L} \mathrm{KIN}$. b Shoot buds induced in medium containing $1.5 \mathrm{mg} / \mathrm{L}$ BAP after 12 days of inoculation. c \& $\mathbf{d}$ Shoot buds start to elongate in medium containing $1.5 \mathrm{mg} / \mathrm{L} \mathrm{BAP}$ and $2.0 \mathrm{mM}$ spermidine after 21 days of inoculation. e Elongated shoots after 42 days of inoculation. f Plants grown in half strength MS medium without any PGR. g A complete plantlets with well developed root system ready for field transfer. $\mathbf{h}$ Tissue culture derived ex vitro field grown micropropagated plants 
(Tween-20) solution for $2 \mathrm{~min}$. Finally, the explants were surface-disinfected with mercuric chloride $\left(\mathrm{HgCl}_{2}\right)$ solution $(0.1 \%, w / v)$ for $8 \mathrm{~min}$ and rinsed 3 times with sterile distilled water. Then all the explants were implanted on Murashige and Skoog (MS) [20] basal medium without any plant growth regulator (PGR) for the establishment of an initial sterile culture.

\section{Micropropagation}

The mature leaves $(12-15 \mathrm{~mm})$ were cut from the in vitro established infection-free plants and were used as initial explants for micropropagation purpose. Two different cytokinins viz. 6-Benzylaminopurine (BAP) and Kinetin $(\mathrm{KIN})$ are tested in six different concentrations $(0.5,1.0$, $1.5,2.0,2.5,3.0 \mathrm{mg} / \mathrm{L})$. The effect of Spermidine (1.0, 1.5, 2.0, $2.5 \mathrm{mM}$ ) in combination with optimum cytokinin was also evaluated for better results. After 3 weeks, all the explants were subcultured to their respective fresh medium for the elongation of the adventitious shoots. After another 3 weeks, all cultures were transferred to halfstrength MS medium without any PGR for further elongation and in vitro rooting. Ultimately, the micropropagated plants with well developed root systems, were acclimatized and transferred to the field conditions following the methods previously standardized by us [21].

\section{Extract preparation for antimicrobial screening}

Fresh leaves of both in vitro cultured and ex vitro, field grown micropropagated plants were collected and air dried in closed and dark environment at $40{ }^{\circ} \mathrm{C}$ for 7 days. Dry leaves were powdered in mixture grinder and kept at $4{ }^{\circ} \mathrm{C}$ for further use. The powdered plant material was extracted in three different solvent (methanol, ethanol, acetone) for $12 \mathrm{~h}$ with the help of Soxlet apparatus. Then the extracts were air dried for $24 \mathrm{~h}$ and finally dissolved in dimethyl sulfoxide (DMSO) to prepare dilution for further study.

\section{Collection and maintenance of test organisms}

A total of 14 microorganisms (9 pathogenic and 5 standard laboratory microorganisms) were used in this experiment. The pathogenic organisms are MDR clinical isolates of human UTI and RTI bacteria (Table 1). The microbial type culture collection (MTCC) strains of three bacteria and two fungi were used as standard test organisms. Different pathogenic and standard bacterial strains of gram negative namely Klebsiella pneumoniae, Escherichia coli, gram positive Bacillus subtilis, Staphylococcus aureus and two standard fungal stains of Aspergillus fumigatus, Candida albicans were tested.

\section{Antimicrobial screening by agar cup method}

The antimicrobial activity was screened by agar well diffusion method. Saborouds dextrose agar was used as the culture media for fungi and Muller Hinton agar medium was used for bacteria. The inoculums were prepared in fresh nutrient broth from well-maintained slant culture. The inoculums were standardized following McFarland

Table 2 Effect of two different cytokinins supplemented with MS basal medium and culture duration (i.e., regeneration cycles) on adventitious shoot induction from leaf explant of Bacopa monnieri

\begin{tabular}{|c|c|c|c|c|c|}
\hline \multicolumn{3}{|c|}{ Concentration of plant growth regulators } & \multirow{2}{*}{$\begin{array}{l}\text { Response } \\
(\%)\end{array}$} & \multirow{2}{*}{$\begin{array}{l}\text { Number of shoot buds } \\
\text { induced per leaf explant } \\
\text { (after } 12 \mathrm{~d} \text { of implantation) }\end{array}$} & \multirow{2}{*}{$\begin{array}{l}\text { No. of elongated }(\geq 1 \mathrm{~cm} \text { ) } \\
\text { shoot buds per leaf explant } \\
\text { (after } 42 \mathrm{~d} \text { of implantation) }\end{array}$} \\
\hline BAP (mg/L) & $\mathrm{KIN}(\mathrm{mg} / \mathrm{L})$ & Spermidine (mM) & & & \\
\hline- & - & - & 0 & $0^{a}$ & $0^{a}$ \\
\hline 0.5 & - & - & 96.7 & $53.5 \pm 1.7^{\mathrm{cd}}$ & $11.7 \pm 0.3^{c}$ \\
\hline 1.0 & - & - & 100 & $76.7 \pm 1.2^{\text {de }}$ & $16.1 \pm 0.2^{d}$ \\
\hline 1.5 & - & - & 100 & $92.4 \pm 3.7^{\mathrm{ef}}$ & $22.5 \pm 0.4^{\mathrm{ef}}$ \\
\hline 2.0 & - & - & 100 & $84.1 \pm 3.2^{e}$ & $19.2 \pm 0.5^{e}$ \\
\hline 2.5 & - & - & 100 & $78.2 \pm 2.4^{\mathrm{e}}$ & $13.8 \pm 0.2^{c d}$ \\
\hline- & 0.5 & - & 90.0 & $45.0 \pm 1.3^{\mathrm{bcd}}$ & $9.5 \pm 0.6^{c}$ \\
\hline- & 1.0 & - & 93.3 & $62.8 \pm 1.9^{\mathrm{d}}$ & $13.6 \pm 0.7^{\mathrm{cd}}$ \\
\hline- & 1.5 & - & 100 & $73.5 \pm 2.2^{\mathrm{de}}$ & $16.0 \pm 0.3^{d}$ \\
\hline- & 2.0 & - & 100 & $81.3 \pm 2.5^{\mathrm{e}}$ & $18.2 \pm 1.0^{\mathrm{de}}$ \\
\hline- & 2.5 & - & 100 & $75.4 \pm 1.9^{\text {def }}$ & $15.4 \pm 0.8^{d}$ \\
\hline 1.5 & - & 1.0 & 100 & $106.0 \pm 3.2^{f}$ & $27.3 \pm 0.7^{f g}$ \\
\hline 1.5 & - & 1.5 & 100 & $114.2 \pm 2.6^{\mathrm{fg}}$ & $30.7 \pm 0.9^{9}$ \\
\hline 1.5 & - & 2.0 & 100 & $123.8 \pm 3.4^{9}$ & $34.9 \pm 1.2^{h}$ \\
\hline 1.5 & - & 2.5 & 100 & $117.6 \pm 3.1^{\mathrm{fg}}$ & $31.4 \pm 1.1^{\mathrm{gh}}$ \\
\hline
\end{tabular}

Each value represents the mean \pm standard error, $n=30$ (3 set, 10 samples in each set). Mean followed by the same letters in each column are not significantly different at $P<0.05$ according to Tukey's multiple range test. BAP 6-Benzylaminopurine, KIN Kinetin 


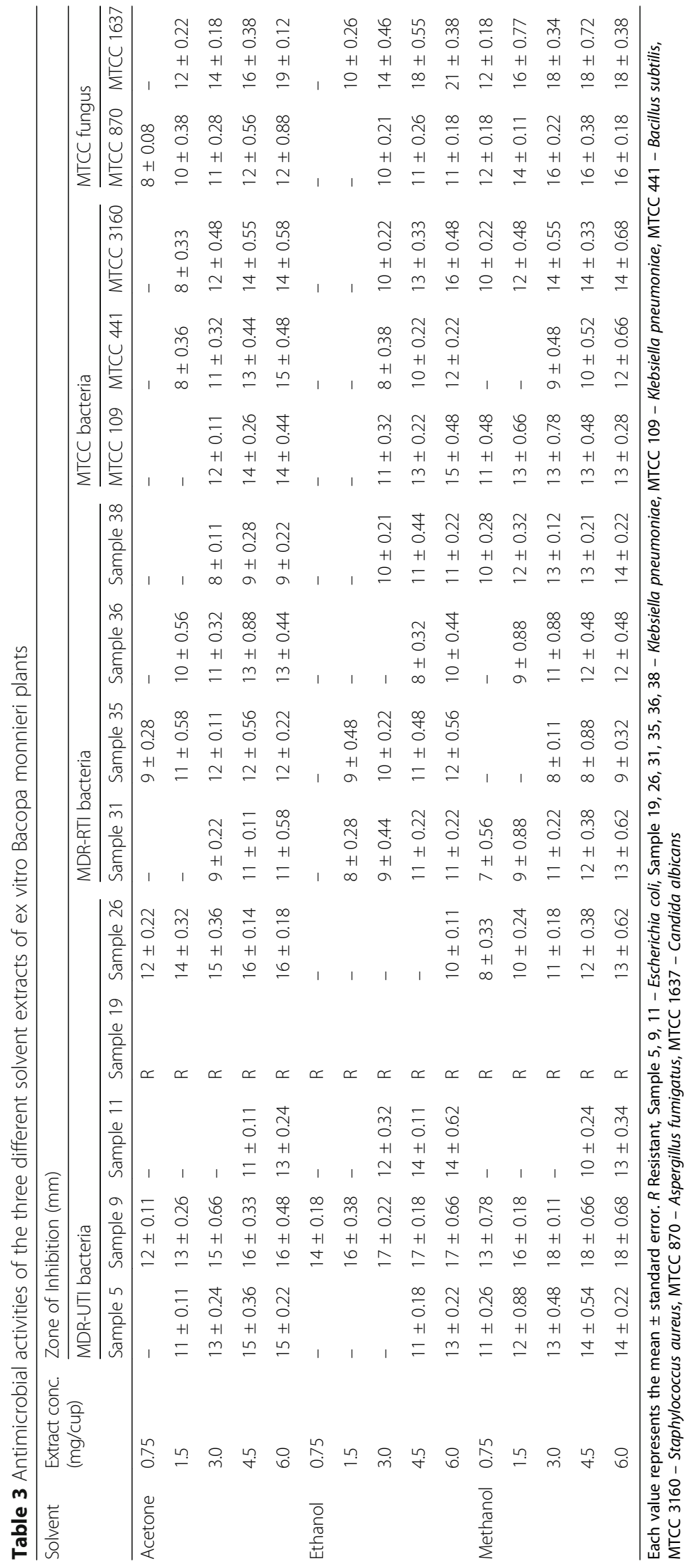


standards by regulating the turbidity of the broth culture by adding sterile broth. Petri dishes were spread with the inoculums and holes $(8 \mathrm{~mm})$ were punctured using sterile cork-borer. The plant extracts of different solvents were dissolved in DMSO and were added to the respective holes. DMSO being the negative control exhibited no zone of inhibition against any of the tested microorganisms. Experimental cultures were incubated for $24 \mathrm{~h}$ at $37{ }^{\circ} \mathrm{C}$ (for bacteria) and $72 \mathrm{~h}$ at $26{ }^{\circ} \mathrm{C}$ (for fungi). After incubation, the zones of inhibition (ZI) were measured and photographed with Canon 'PowerShot SX700 HS' camera.

\section{Minimum inhibitory concentration (MIC)}

The MIC was determined by two fold broth dilution method [22] for showing antimicrobial activity of the plant extract against all the test organisms. The dried plant extracts were resuspended in DMSO to make $100 \mathrm{mg} / \mathrm{mL}$ concentration, then added to broth media using serial dilution. Thereafter $100 \mu \mathrm{l}$ inoculum was added to every tube and incubated at $26{ }^{\circ} \mathrm{C}$ for $72 \mathrm{~h}$ (for fungi) or $37{ }^{\circ} \mathrm{C}$ for $24 \mathrm{~h}$ (for bacteria). The MIC value of both fungi and bacteria was taken as the lowermost concentration of the plant extracts in the tube that exhibited no turbidity following incubation.

\section{Minimum bactericidal and fungicidal concentration (MBC and MFC)}

The minimum bactericidal and fungicidal concentration (MBC and MFC) was determined by the viable cell count method [23] by subculturing $50 \mu \mathrm{l}$ of each dilution used in MIC experiment. Minimum concentration of plant extract, showing no visible growth on subculturing, was taken as MBC or MFC.

\section{Statistical analysis}

In present experimental design, each treatment of micropropagation was repeated thrice with 10 explants per treatment. All data were subjected to one-way analysis of variance (ANOVA) with the help of SPSS software $\left(\mathrm{IBM}^{\bullet}\right.$ SPSS, version 21.0, Chicago, IL). After conducting an ANOVA, the means were further separated using Tukey's test at $P \leq 0.05$ [24]. All types of antimicrobial tests are also repeated three times.

\section{Results}

\section{Micropropagation}

The effect of different concentrations (ranging from $0.5 \mathrm{mg} / \mathrm{L}$ to $2.5 \mathrm{mg} / \mathrm{L}$ ) of BAP and KIN alone on in vitro adventitious shoot multiplication from leaf explants, was investigated (Fig. $1 \mathrm{a}-\mathrm{d}$ ). The adventitious shoot-buds

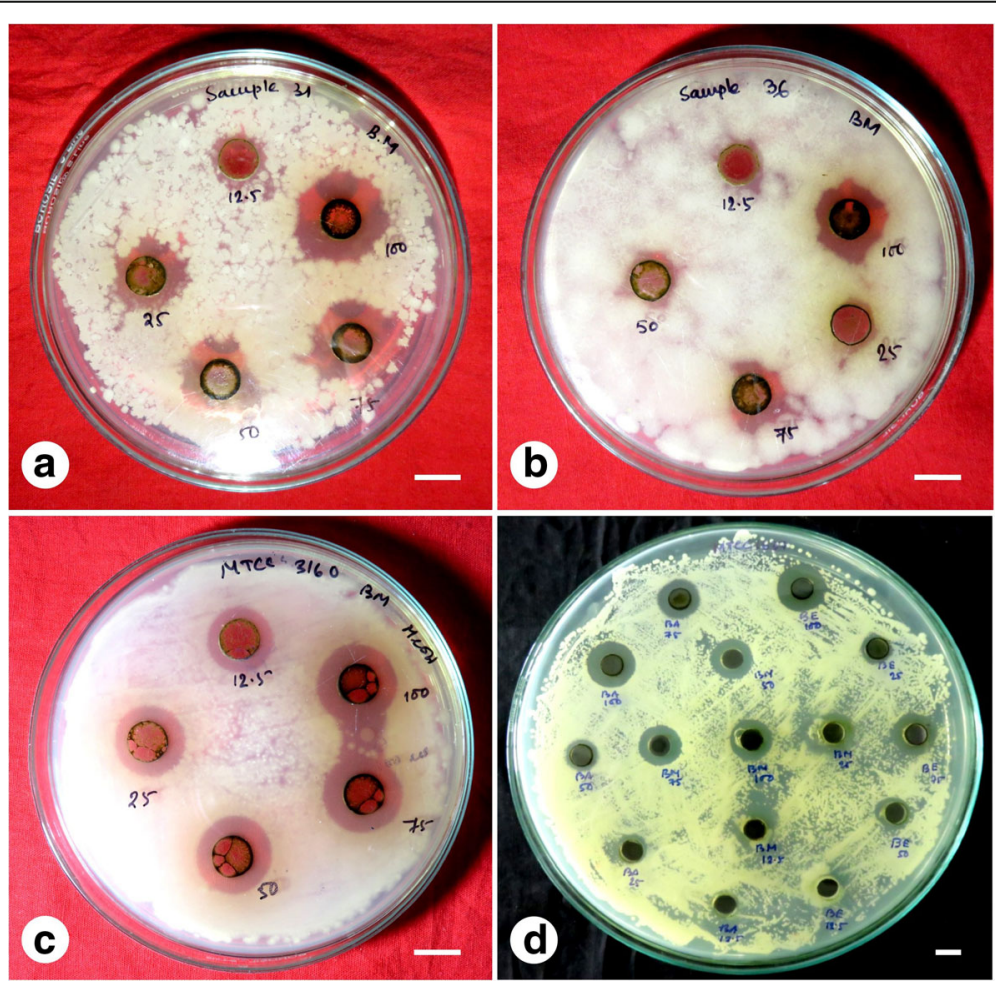

Fig. 2 Antimicrobial activities of Bacopa monnieri [bar $=10 \mathrm{~mm}$. a Activities of methanol extract against MDR-RTI clinical strain Klebsiella pneumoniae [Sample 31], (b) Activities of methanol extract against MDR-RTI clinical strain Klebsiella pneumoniae [Sample 36], (c) Activities of methanol extract against standard bacterial strain Staphylococcus aureus [MTCC 3160], (d) Activities of ethanol, methanol, and acetone extracts against standard fungal strain Candida albicans [MTCC 1637] 
were induced from the cut edges within 6 to 7 days of implantation, followed by swelling at the cut edges. A total of 92.4 shoot buds were induced after 12 days of culture in MS basal medium containing $1.5 \mathrm{mg} / \mathrm{L} \mathrm{BAP}$, whereas maximum of 81.3 shoot buds were induced in the presence of KIN $(2.0 \mathrm{mg} / \mathrm{L})$ after same duration (Table 2). Greater concentration of cytokinin is not only abridged the quantity of shoot buds, but also suppressed the growth of the multiplied shoots. Spermidine in combination with the optimum concentration of BAP $(1.5 \mathrm{mg} / \mathrm{L})$ significantly increased the rate of shoot induction. MS basal medium supplemented with $1.5 \mathrm{mg} / \mathrm{L} \mathrm{BAP}$ and $2.0 \mathrm{mM}$ spermidine was found to be the best combination of growth regulators with a maximum of 123.8 shoot buds per leaf explant, after 12 days of culture.
Although the huge numbers of shoot buds were induced, the elongation of these newly induced buds was a real problem and few of them had elongated at a time in presence of cytokinin only. Spermidine had played an affirmative role on shoot bud elongation in B. monnieri. Only 22.5 shoot buds are elongated in the presence of $1.5 \mathrm{mg} / \mathrm{L}$ BAP alone, but this numbers increased up to 34.9 when supplemented with $2.0 \mathrm{mM}$ spermidine along with $1.5 \mathrm{mg} / \mathrm{L}$ BAP (Fig. 1e). Further elongation and in vitro rooting was achieved in half strength of MS medium without any PGR (Fig. 1f). A maximum of 13.2 roots per shoot with a length of $4.5 \mathrm{~cm}$ was noted within 18 day of implantation (Fig. $1 \mathrm{~g}$ ). In vitro derived plantlets were successfully acclimatized with a survival rate of $96.7 \%$. All the plants were grown healthily with a morphology alike to that of the source plants (Fig. 1h).

Table $4 \mathrm{MIC}$ and MBC/MFC (mg/mL) of the three different solvents of ex vitro plants of Bacopa monnieri

\begin{tabular}{|c|c|c|c|c|c|c|}
\hline \multicolumn{3}{|c|}{ Microorganisms } & \multirow{2}{*}{$\begin{array}{l}\text { Inhibition } \\
\text { type }\end{array}$} & \multicolumn{3}{|c|}{ Inhibiting/cidal concentrations $(\mathrm{mg} / \mathrm{mL}$ ) of different solvent extracts } \\
\hline Type & Bacteria / fungi & Strain & & Acetone & Ethanol & Methanol \\
\hline \multirow[t]{18}{*}{ Pathogenic } & MDR-UTI bacterial strains & Sample 5 & $\mathrm{MIC}$ & 5.0 & 7.5 & 5.0 \\
\hline & & & MBC & 10.0 & 12.5 & 12.5 \\
\hline & & Sample 9 & MIC & 5.0 & 2.5 & 2.5 \\
\hline & & & MBC & 10.0 & 5.0 & 5.0 \\
\hline & & Sample 11 & MIC & 5.0 & 5.0 & 7.5 \\
\hline & & & $\mathrm{MBC}$ & 12.5 & 10.0 & 12.5 \\
\hline & & Sample 19 & MIC & R & $\mathrm{R}$ & $\mathrm{R}$ \\
\hline & & & $\mathrm{MBC}$ & R & $\mathrm{R}$ & $\mathrm{R}$ \\
\hline & & Sample 26 & MIC & 2.5 & 25.0 & 10.0 \\
\hline & & & $\mathrm{MBC}$ & 5.0 & 30.5 & 17.5 \\
\hline & MDR-RTI bacterial strains & Sample 31 & MIC & 7.5 & 7.5 & 10.0 \\
\hline & & & $\mathrm{MBC}$ & 10.0 & 12.5 & 15.0 \\
\hline & & Sample 35 & MIC & 7.5 & 5.0 & 15.0 \\
\hline & & & $\mathrm{MBC}$ & 12.5 & 7.5 & 17.5 \\
\hline & & Sample 36 & MIC & 5.0 & 10.0 & 7.5 \\
\hline & & & $\mathrm{MBC}$ & 10.0 & 15.0 & 15.0 \\
\hline & & Sample 38 & MIC & 15.0 & 12.5 & 5.0 \\
\hline & & & $\mathrm{MBC}$ & 17.5 & 17.5 & 7.5 \\
\hline \multirow[t]{10}{*}{ Standard } & MTCC bacterial strains & MTCC 109 & $\mathrm{MIC}$ & 5.0 & 5.0 & 7.5 \\
\hline & & & $\mathrm{MBC}$ & 12.5 & 12.5 & 12.5 \\
\hline & & MTCC 441 & $\mathrm{MIC}$ & 7.5 & 12.5 & 10.0 \\
\hline & & & $\mathrm{MBC}$ & 10.0 & 17.5 & 15.0 \\
\hline & & MTCC 3160 & MIC & 10.0 & 15.0 & 2.5 \\
\hline & & & $\mathrm{MBC}$ & 12.5 & 22.5 & 7.5 \\
\hline & MTCC fungal strains & MTCC 870 & MIC & 2.5 & 10.0 & 2.5 \\
\hline & & & MFC & 7.5 & 12.5 & 5.0 \\
\hline & & MTCC 1637 & MIC & 7.5 & 7.5 & 1.25 \\
\hline & & & MFC & 12.5 & 12.5 & 5.0 \\
\hline
\end{tabular}

$R$ Resistant, Sample 5, 9, 11 - Escherichia coli, Sample 19, 26, 31, 35, 36, 38 - Klebsiella pneumoniae, MTCC 109 - Klebsiella pneumoniae, MTCC 441 - Bacillus subtilis, MTCC 3160 - Staphylococcus aureus, MTCC 870 - Aspergillus fumigatus, MTCC 1637 - Candida albicans 


\section{Antimicrobial activity}

In the present study, all UTI and RTI strains, collected from the patients, were routinely categorized in our laboratory, and examined individually for the resistance pattern against multidrug (Table 1). Result in the present study revealed that all the extracts (ethanol, methanol and acetone) of $B$. monnieri were more or less effective against all the test organisms except one (Sample 19) (Table 3). Overall, methanolic extract proved more effective than other two extracts with very clear ZI (Fig. 2a-c). In case of MDR-UTI strain of E. coli (Sample 9) methanolic extract exhibited maximum inhibition (ZI $18 \mathrm{~mm}$ ), whereas another strain of E. coli (Sample 5) and $K$. pneumoniae (Sample 26) showed maximum inhibition (ZI $15 \mathrm{~mm}$ and $16 \mathrm{~mm}$ respectively) with acetone extract. For MDR-RTI bacteria, methanol extract showed maximum inhibition (ZI $14 \mathrm{~mm}$ ) against $K$. pneumoniae (Sample 38). In case of all three MTCC bacteria, the maximum inhibition was noted with acetone extract. The fungal strain of C. albicans (MTCC 1637) showed maximum inhibition (ZI $21 \mathrm{~mm}$ ) with ethanolic extract (Fig. 2d).

All the three types of extracts of B. monnieri were found to show potential anti-UTI and anti-RTI activity with MIC values ranging between $2.5-25.0 \mathrm{mg} / \mathrm{mL}$. The MIC range was noted to be comparatively lower $(1.25-10.0 \mathrm{mg} / \mathrm{mL})$ against two fungal strains. In case of UTI and RTI bacteria, all the extracts exhibited MBC/MIC ratio less than " 32 ", which indicated that the test extracts of $B$. monnieri were bactericidal rather than bacteriostatic. Methanol was found to be the most potent (MIC $2.5-15.0 \mathrm{mg} / \mathrm{mL}$ ), while acetone and ethanol showed more or less similar inhibitory activity (MIC $2.5-25.0 \mathrm{mg} / \mathrm{mL}$ and $2.5-30.0 \mathrm{mg} / \mathrm{mL}$ respectively) against all the microorganisms tested including MDR-UTI and MDR-RTI pathogens. Therefore, among all the test extracts, methanol was most potent against both bacteria and fungi (Table 4).

The antibacterial and antifungal activity of ex vitro plants is slightly better compared to the in vitro plants; however, the potency of the in vitro plants is not also negligible (Fig. 3).

\section{Discussion}

The cytokinin BAP or KIN alone was sufficient for induction of adventitious shoot buds from the leaf explants of B. monnieri. Higher concentration of cytokinin had reduced the number of shoots, a finding similar to that noted in Tylophora indica [19]. BAP was found to be more effective than KIN for adventitious shoot induction in B. monnieri. Similar results were reported in Capsicum frutescens where BAP proved to be the best among four of the cytokinins tested [25]. Micropropagation methods of $B$. monnieri have been studied by many groups for more than four decades

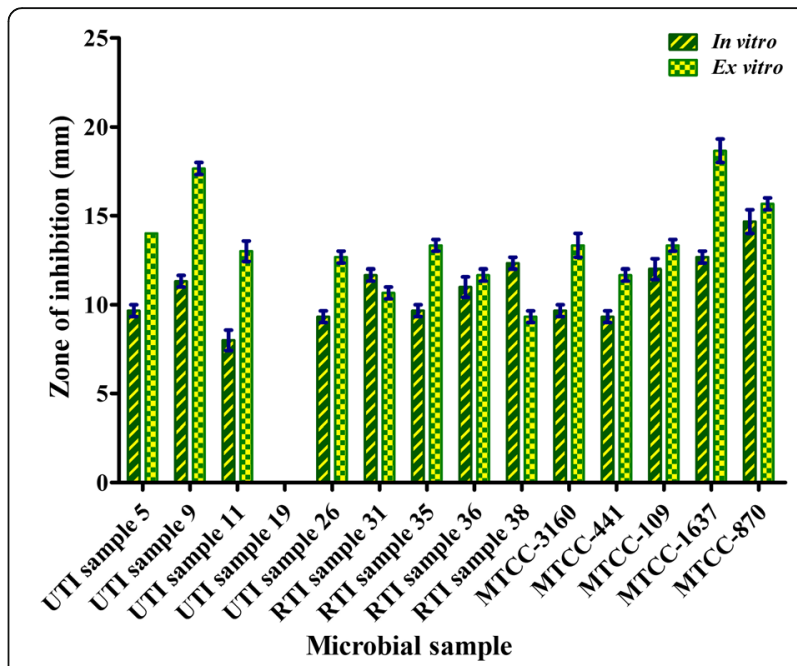

Fig. 3 Antimicrobial activities of the methanolic extracts of in vitro and ex vitro raised plants of Bacopa monnieri. (Sample 5, 9, 11, 19, $26,31,35,36$, and 38 are clinical isolates of MDR human UTI and RTI bacteria; MTCC 109, 441 and 3160 are standard bacterial strains and MTCC 870 and 1637 are standard fungal strains of microbial type culture collection (MTCC)

and till the research is continuing for improvement of these protocols [2, 3, 26-30]. So far, to our present knowledge, the present manuscript is the first report describing the promoting role of spermidine on micropropagation of $B$. monnieri. The addition of spermidine along with the optimum concentration of BAP has proven helpful in increasing the adventitious shoot bud induction rate of B. monnieri. Chi et al. [31] had also described the enhancing role polyamines in the shoot regeneration of Brassica campestris. Polyamines have been found to act as a growth stimulant and sometimes as the enhancer of the action of PGRs [32]. Polyamines play crucial role in the growth and development of higher plants by influencing cell division, stem elongation, root growth and many other functions [33]. Present findings showed the exogenous application of spermidine had not only enhanced the shoot induction rate, but also had significantly improved the growth and elongation of the adventitious shoots in B. monnieri. The similar optimistic role of polyamines, especially spermidine, on the growth and development of plants was previously reported by several authors [25, 34].

The antimicrobial property of B. monnieri was previously reported by few researchers against several standard bacterial strains [10-12, 35]. Only Hema et al. [13] had described the antimicrobial property of $B$. monnieri against clinical isolates of human pathogenic strains, but these are not MDR strains. Antibacterial resistance has become one of the grave public health concerns, globally, over the last two decades [14, 15]. Particularly, MDR is a major concern in present day medical science. 
In this study standard laboratory microorganisms as well as MDR-UTI and MDR-RTI pathogens are found to be susceptible to various extracts of $B$. monnieri. The wonder plant $B$. monnier $i$ is pharmaceutically very significant as it contains many secondary metabolites viz. alkaloids, flavonoid, phenolic, glycosides, and other substances like stigmastanol, stigmasterol and $\beta$-sitosterol, triterpene oligoglycosides, bacomosaponins $\mathrm{A}$ and $\mathrm{B}$, bacomosides A, B1, and B2 [4, 9]. A group of secondary metabolite compounds has effective antimicrobial properties [36]. Mainly, methanol extract contains more antioxidant as because of this it might be used as folk medicide [37]. It was also reported that the methanol extract of B. monnieri exhibited the more significant inhibitory effect against Klebsiella pneumoniae, Staphylococcus aureus which corroborates with our findings [38, 39]. Similar to our findings against Candida albicans Canli et al. [40] also reported that the ethanolic extract exhibited best anti-fungal activity among all other solvent extracts against Lycoperdon lividum.

The study of in vitro and ex vitro plants exhibited the antimicrobial activity was better in ex vitro field grown plants than in vitro plants (Fig. 3). With a similar approach, a comparative study was conducted by few researchers in recent past [41-44]. Some of them reported the in vitro plants exhibited more antimicrobial activity as compared to ex vitro plants [42, 43], whereas the majority of them reported ex vitro plants are superior or more or less comparable as compare to in vitro plants $[41,44]$. The in vitro plants, producing secondary metabolites at a primary stage of growth, provides an opportunity for fast production of pharmacologically important compounds that can be utilized for medicinal purposes [41].

Bacterial resistance against existing drugs has directed to severe health concerns all over the world [45]. Our present findings confirm that $B$. monnieri is very effective against MDR-UTI and RTI clinical isolates, where majority of the commercially available antibiotics are unable to treat those. Similarly, in very recent times few researchers had reported that B. monnieri proved to be effective against clinical isolates of Escherichia coli, Klebsiella pneumoniae [13] and Staphylococcus aureus [46]; although their pathogens are not MDR strains. Because of B. monnieri contains many bioactive metabolite, the crude extract shows more effectiveness rather than commercial antibiotics. In addition, the herbal formulation have no side effect, which is an important advantage over commercial antibiotics. The determination of minimum lethal concentration (MLC), also known as the MBC or MFC, is the most common estimation of bactericidal or fungicidal activity [16]. Overall, present study exhibited a substantial bactericidal activity of the tested extracts of $B$. monnieri against the clinical isolates of MDR-UTI and RTI strains as indicated by the $\mathrm{MBC} / \mathrm{MIC}$ ratio less than "32" [47].

\section{Conclusion}

The present manuscript described a very reliable method for large scale multiplication of B. monnieri. In addition, present findings show the methanolic extract of $B$. monneari have potential antimicrobial activity against clinical isolates of MDR-UTI and MDR-RTI bacterial strains. In future this plant may be used to treat these infectious diseases. Though in vitro plants show slightly lesser antimicrobial potency as compared to ex vitro plants, they can be produced in large quantities using very little space throughout the year. Present protocol can be commercially implemented by pharmaceutical industries to address cumulative market demand of B. monnieri.

\section{Acknowledgements \\ SMH acknowledges the Ministry of Minority Affairs and University Grant Commission for providing the Maulana Azad National Fellowship. SMH, AC and BG thankful to Swami Kamalasthananda, Principal, Ramakrishna Mission Vivekananda Centenary College, Rahara, Kolkata (India), for the facilities provided for the present study. DD acknowledges technical and management support provided by Ashok Laboratory Clinical Testing Centre. Private Limited, Kolkata.}

\section{Authors' contributions \\ $\mathrm{SMH}$ performed all the plant tissue culture related experiments and write up a part of manuscript. AC screened the antimicrobial activities of plant extracts and write up a part of manuscript. DD collected the clinical isolates and checked their response against multidrug. SM and SN was involved in result interpretation and made necessary correction in the write up. Critical revision of the article was done by SM, SN and BG. Conception, experiment design, overall monitoring and final approval of the article was done by BG. All authors read and approved the final manuscript.}

Competing interests

All authors declare that they have no competing interests.

\section{Publisher's Note}

Springer Nature remains neutral with regard to jurisdictional claims in published maps and institutional affiliations.

\section{Author details}

'Plant Biotechnology Laboratory, Post Graduate Department of Botany, Ramakrishna Mission Vivekananda Centenary College, Rahara, Kolkata 700118, India. ${ }^{2}$ Department of Microbiology, Ashok Laboratory Clinical Testing Centre Private Limited, Kolkata 700068, India. ${ }^{3}$ Department of Microbiology, Dinabandhu Andrews College, Garia, Kolkata 700084, India. ${ }^{4}$ Centre of Biotechnology, Siksha O Anusandhan University, Bhubaneswar 751030, India.

Received: 22 April 2017 Accepted: 14 August 2017

Published online: 27 September 2017

\section{References}

1. Gobalakrishnan R, Kulandaivelu M, Bhuvaneswari R, Kandavel D, Kannan L. Screening of wild plant species for antibacterial activity and phytochemical analysis of Tragia involucrata L. J Pharm Anal. 2013;3:460-5.

2. Tiwari $\mathrm{V}$, Tiwari $\mathrm{KN}$, Singh BD. Shoot bud regeneration from different explants of Bacopa monniera (L.) Wettst by trimethoprim and bavistin. Plant Cell Rep. 2006;25:629-35.

3. Ramesh M, Vijayakumar KP, Karthikeyan A, Pandian SK. RAPD based genetic stability analysis among micropropagated, synthetic seed derived and hardened plants of Bacopa monnieri (L.): a threatened Indian medicinal herb. Acta Physiol Plant. 2011;33:163-71.

4. Zhou Y, Shen YH, Zhang C, Zhang WD. Chemical constituents of Bacopa monnieri. Chem Nat Compd. 2007:43:355-7.

5. Rajani M. Bacopa monnieri, a nootropic drug. In: Ramawat KG, Mérillon JM, editors. Bioactive molecules and medicinal plants. New York: Springer; 2008 p. 175-95. 
6. Kishore K. Brahmi: a complete herbal medicine. J Pharm Res. 2012;5:3139-42.

7. Al-Snafi AE. The pharmacology of Bacopa monniera. A review, Int J Pharma Sci Res. 2013;4:154-9.

8. Aguiar S, Borowski T. Neuropharmacological review of the nootropic herb Bacopa monnieri. Rejuvenation Res. 2013;16:313-26.

9. Ohta T, Nakamura S, Nakashima S, Oda Y, Matsumoto T, Fukaya M, Yano M, Yoshikawa M, Matsuda $\mathrm{H}$. Chemical structures of constituents from the whole plant of Bacopa monniera. J Nat Med. 2016;70:404-11.

10. Sampathkumar $P$, Dheeba B, Venkatasubramanian $V$, Arulprakash $T$, Vinothkannan R. Potential antimicrobial activity of various extracts of Bacopa monnieri (Linn.). Int J of Pharmacol. 2008:4:230-2.

11. Alam K, Parvez N, Yadav S, Molvi K, Hwisa N, Sharif SMA, Pathak D, Murti Y, Zafar R. Antimicrobial activity of leaf callus of Bacopa monnieri L. Pharm Lett. 2011:3:287-91.

12. Joshi BB, Patel MGH, Dabhi B, Mistry KN. In vitro phytochemical analysis and anti-microbial activity of crude extract of Bacopa monniera. Bull Pharma Med Sci. 2013:1:128-31.

13. Hema TA, Arya AS, Subha S, John CRK, Divya PV. Antimicrobial activity of five South Indian medicinal plants against clinical pathogens. Int J Pharm Bio Sci. 2013;4:70-80

14. Dey D, Ray R, Hazra B. Antimicrobial activity of pomegranate fruit constituents against drug-resistant Mycobacterium tuberculosis and $\beta$ lactamase producing Klebsiella pneumoniae. Pharm Biol. 2015;53:1474-80.

15. Dey D, Ray R, Hazra B. Antitubercular and antibacterial activity of quinonoid natural products against multi-drug resistant clinical isolates. Phytother Res. 2014;28:1014-21.

16. Balouiri M, Sadiki M, Ibnsouda SK. Methods for in vitro evaluating antimicrobial activity:A review. J Pharm Anal. 2016;6:71-9.

17. National Medicinal Plants Board. Thirty two prioritized medicinal plants, National Informatics Centre, Ministry of Health and Family Welfare, Department of Ayush, Government of India. 2004.

18. Karthikeyan A, Madhanraj A, Pandian SK, et al. Genetic variation among highly endangered Bacopa monnieri (L.) Pennell from Southern India as detected using RAPD analysis. Genet Resour Crop Evol. 2011;58:769-82.

19. Haque SM, Ghosh B. Field evaluation and genetic stability assessment of regenerated plants produced via direct shoot organogenesis from leaf explant of an endangered "Asthma plant" (Tylophora indica) along with their in vitro conservation. Natl Acad Sci Lett. 2013;36:551-62.

20. Murashige T, Skoog F. A revised medium for rapid growth and bioassays with tobacco tissue culture. Physiol Plant. 1962:15:473-97.

21. Haque SM, Ghosh B. Micropropagation, in vitro flowering and cytological studies of Bacopa chamaedryoides, an ethno-medicinal plant. Environ Exp Biol. 2013;11:59-68.

22. Wiegand I, Hilpert K, Hancock REW. Agar and broth dilution methods to determine the minimal inhibitory concentration (MIC) of antimicrobial substances. Nat Protoc. 2008;3:163-75.

23. Toda M, Okubo S, Hiyoshi R, Shimamura T. The bactericidal activity of tea and coffee. Lett Appl Microbiol. 1989;8:123-5.

24. Haynes W, Tukey's test, In: Encyclopedia of systems biology. Dubitzky W, Wolkenhauer O, Cho K-H, et al. editors. New York: Springer; 2013. p. 2303-2304.

25. Kumar V, Sharma A, Prasad BCN, Gururaj HB, Giridhar P, Ravishankar GA. Direct shoot bud induction and plant regeneration in Capsicum frutescens Mill.: influence of polyamines and polarity. Acta Physiol Plant. 2007:29:11-8.

26. Thakur S, Ganpathy PS, Johri BN. Differentiation of abnormal plantlets in Bacopa monnieri. Phytomorphology. 1976;26:422-4.

27. Banerjee M, Shrivastava S. An improved protocol for in vitro multiplication of Bacopa monnieri (L.). World J Microbiol Biotechnol. 2008;24:1355-9.

28. Ceasar SA, Maxwell SLPKB, Karthigan M, Ignacimuthu S. Highly efficient shoot regeneration of Bacopa monnieri (L.) using a two-stage culture procedure and assessment of genetic integrity of micropropagated plants by RAPD. Acta Physiol Plant. 2010;32:443-52.

29. Kumari U, Vishwakarma RK, Gupta N, Ruby SMV, Khan BM. Efficient shoots regeneration and genetic transformation of Bacopa monniera. Physiol Mol Biol Plants. 2015:21:261-7.

30. Largia MJV, Shilpha J, Pothiraj G, Ramesh M. Analysis of nuclear DNA content, genetic stability, Bacoside A quantity and antioxidant potential of long term in vitro grown germplasm lines of Bacopa monnieri (L.). Plant Cell Tissue Organ Cult. 2015;120:399-406.

31. Chi CL, Lin WS, Lee JEE, Pua EC. Role of polyamines on de novo shoot morphogenesis from cotyledons of Brassica campestris ssp. pekinensis (Lour) Olsson in vitro. Plant Cell Rep. 1994;13:323-9.
32. Moshkov IE, Novikova GV, Hall MA, George EF. Plant growth regulators III: ethylene, abscisic acid, their analogues and inhibitors, miscellaneous compounds. In: George EF, Hall MA, de Klerk GJ, editors. Plant propagation by tissue culture. 3rd ed. Netherlands: Springer; 2008. p. 227-82.

33. Podwyszyn' ska M, Kosson R, Treder J. Polyamines and methyl jasmonate in bulb formation of in vitro propagated tulips. Plant Cell Tissue Organ Cult. 2015;123:591-605

34. Satish L, Rency AS, Rathinapriya P, Ceasar SA, Pandian S, Rameshkumar R, Rao TB, Balachandran SM, Ramesh M. Influence of plant growth regulators and spermidine on somatic embryogenesis and plant regeneration in four Indian genotypes of finger millet (Eleusine coracana L. Gaertn). Plant Cell Tissue Organ Cult. 2016;124:15-31.

35. Ghosh T, Maity TK, Bose A, Dash GK, Das M. Antimicrobial activity of various fractions of ethanol extract of Bacopa monnieri Linn. aerial parts. Indian J Pharm Sci. 2007:69:312-4.

36. Banasiuk R, Kawiak A, Krolicka A. In vitro cultures of carnivorous plants from the Drosera and Dionaea genus for the production of biologically active secondary metabolites. Bio Technologia. 2012;93:87-96.

37. Hossain MS, Rahman MS, Imon AHMR, Zaman S, ASMBA S, Mondal M, SarwarA HTB, Adhikary BC, Begum T, Tabassum A, Alam S, Begum MM. Ethnopharmacological investigations of methanolic extract of Pouzolzia Zeylanica (L.) Benn. Clin Phytosci. 2016:2:10.

38. Rajashekharappa S, Krishna V, Sathyanarayana BN, Gowdar HB. Antibacterial activity of bacoside-A- an active constituent isolated of Bacopa monnieri (L.) Wettest. Pharmacologyonline. 2008;2:517-28.

39. Mathur A, Verma SK, Purohit R, Singh SK, Mathur D, Prasad GBKS, Dua VK. Pharmacological investigation of Bacopa monnieri on the basis of antioxidant, antimicrobial and anti-inflammatory properties. J Chem Pharm Res. 2010:2:191-8.

40. Canli K, Altuner EM, Akata I, Turkmen Y, Uzek U. In vitro antimicrobial screening of Lycoperdon lividum and determination of the ethanol extract composition by gas chromatography/mass spectrometry. Bangladesh J Pharmacol. 2016;11:389-94.

41. Ncube B, Ngunge VNP, Finnie JF, Van Staden J. A comparative study of the antimicrobial and phytochemical properties between outdoor grown and micropropagated Tulbaghia violacea Harv. plants. J Ethnopharmacol. 2011; 134:775-80.

42. Kumari A, Baskaran P, Van Staden J. In vitro propagation and antibacterial activity in Cotyledon orbiculata: a valuable medicinal plant. Plant Cell Tissue Organ Cult. 2016;124:97-104

43. Baskaran $P$, Singh S, Van Staden J. In vitro propagation, proscillaridin A production and antibacterial activity in Drimia robusta. Plant Cell Tissue Organ Cult. 2013;114:259-67.

44. Khateeb WA, Hussein E, Qouta L, Datt MA, Shara BA, Abu-zaiton A. In vitro propagation and characterization of phenolic content along with antioxidant and antimicrobial activities of Cichorium pumilum Jacq. Plant Cell Tissue Organ Cult. 2012;110:103-110.

45. Phull A-R, Abbas Q, Ali A, Raza H, Kim S-J, Zia M, Haq IU. Antioxidant, cytotoxic and antimicrobial activities of green synthesized silver nanoparticles from crude extract of Bergenia ciliate. Future J Pharma Sci. 2016;2:31-6.

46. Emran TB, Rahman MA, Uddin MMN, Dash R, Hossen MF, Mohiuddin M, Alam MR. Molecular docking and inhibition studies on the interactions of Bacopa monnieri's potent phytochemicals against pathogenic Staphylococcus aureus. DARU J Pharma Sci. 2015;23:26.

47. Cockerill FR. Conventional and genetic laboratory tests used to guide antimicrobial therapy. Mayo Clin Proc. 1998;73:1007-21. 